\title{
Detection of canine anti-DEA 1 antibodies using flow cytometry in dogs following DEA 1-positive blood transfusion
}

\author{
Detecção de anticorpos caninos anti-AEC 1 por citometria de fluxo em cães \\ pós-transfundidos com sangue AEC 1 positivo
}

\author{
Suzana Cláudia Spinola dos SANTOS ${ }^{1}$; Ludmila Rodrigues MOROZ²; Mariane Melo dos SANTOS \\ Allan Souza dos SANTOS 3 ; Soraya Castro TRINDADE; Roberto MEYER ${ }^{3}$; Maria de Fátima Dias COSTA ${ }^{4}$ \\ ${ }^{1}$ Universidade Federal da Bahia, Instituto de Ciências da Saúde, Programa de Pós-Graduação em \\ Processos Interativos dos Órgãos e Sistemas, Salvador - BA, Brazil \\ ${ }^{2}$ Universidade Federal da Bahia, Hospital de Medicina Veterinária, Laboratório de Patologia Clínica, Salvador - BA, Brazil \\ ${ }^{3}$ Universidade Federal da Bahia, Instituto de Ciências da Saúde, Laboratório de Imunologia e Biologia Molecular, Salvador - BA, Brazil \\ ${ }^{4}$ Universidade Federal da Bahia, Instituto de Ciências da Saúde, Laboratório de Neuroquímica e Biologia Celular, Salvador - BA, Brazil
}

\begin{abstract}
The shortage of blood donor dogs in veterinary emergencies can lead to blood transfusions between animals whose blood type has not been identified. The antibody profile serves as a warning sign for animals that require a second blood transfusion, which is only advisable from compatible donor dogs. This article focuses on the determination of anti-DEA 1 antibodies using the flow cytometry technique in dogs that have undergone a transfusion using DEA 1-positive blood, compared to results obtained from crossmatching. Blood from 18 DEA 1-positive donors ranked according to the chromatographic technique was used to transfuse thirty-three animals with unknown blood types and which demonstrated negative crossmatching to donors. On post-transfusion days $7,14,21$ and $28,45 \%$ and $27 \%$ of the animals tested positive for the anti-DEA 1 antibody, through crossmatching and flow cytometry, respectively. Detecting antibodies using the flow cytometric technique has high specificity and sensitivity, while crossmatching methods are highly sensitive but manifest low specificity. Following the blood transfusion, animals that did not present as positive through crossmatching or flow cytometry were considered different from all other DEA 1-positive blood groups. Keywords: Alloantibodies. Canine antibodies. DEA 1. Blood transfusion in dogs.
\end{abstract}

\section{Resumo}

A escassez de cães doadores de sangue em situações de emergência na Medicina Veterinária podelevarà realizaçãode transfusões de sangue entre animais que não tiveram seu tipo sanguíneo previamente determinado. O padrão de anticorpos serve como um sinal de alerta para animais que serão submetidos a uma segunda transfusão sanguínea, sendo esta recomendável somente se o sangue for proveniente de cães doadores compatíveis. Este artigo aborda a determinação de anticorpos anti-AEC 1 pela técnica de citometria de fluxo em cães que receberam uma transfusão utilizando sangue do grupo AEC 1 positivo, comparando-se os resultados com aqueles obtidos a partir de reação cruzada. Foi utilizado o sangue de 18 animais doadores do tipo AEC 1 positivo classificados por técnica cromatográfica, a fim de transfundir trinta e três animais com tipos sanguíneos desconhecidos e que demonstraram reação cruzada negativa aos doadores. Nos dias 7, 14, 21 e 28 pós-transfusão, $45 \%$ e $27 \%$ dos animais mostraramse positivos para os anticorpos anti-AEC 1, respectivamente, pela reação cruzada e através de citometria de fluxo. A pesquisa de anticorpos com o emprego da técnica de citometria de fluxo tem alta especificidade e sensibilidade, enquanto a reação cruzada, altamente sensível, tem baixa especificidade. Animais que não apresentaram positividade após a transfusão de sangue na reação cruzada e na citometria de fluxo foram considerados como pertencentes a grupos sanguíneos diferentes do AEC 1 positivo.

Palavras-chave: Isoanticorpos. Anticorpos caninos. AEC 1. Transfusão sanguínea em cães.

Correspondence to:

Suzana Cláudia Spinola dos Santos

Universidade Federal da Bahia, Instituto de Ciências da Saúde

Av. Reitor Miguel Calmon, 1272

CEP 40231-300, Salvador, BA, Brazil

e-mail: suzanaspinola@gmail.com

Received: $24 / 10 / 2016$

Approved: 07/11/2017

\section{Introduction}

Although blood transfusions can save lives, they also present risks and do not guarantee absolute security for transfused animals. Immune-mediated reactions may be caused by antibody interactions with antigens present in allogeneic cells or with proteins present in plasma (DAVIDOW, 2013; KOHN et al., 2014). Alloimmunization in dogs occurs when there is a sensitization of the immune system by other antigens. 
Alloantibodies against dog erythrocyte antigen (DEA) 1 (1.1, 1.2), 3, 5, 7 and Dal occur after contact with a receiver that does not have this blood type (BLAIS et al., 2007; KESSLER et al., 2010). These reactions have been described in dogs but have not been characterized individually, due to limited viability of classification procedures and lack of comparative studies between different blood group systems and reagents (BLOIS et al., 2013; ACIERNO et al., 2014). According to Giger (2014), the strong antigenicity of DEA 1 means that donor blood typing is recommended. Canine blood typing is based on serologic identification through agglutination reactions, although serum from sensitized dogs has been used for typing; however, these polyvalent alloantibodies vary from batch to batch. In theory, the ideal blood donor is a dog that is negative for DEA 1 (1.1, 1.2), 3, 5 and 7. However, due to the high population frequency of DEA 1, that includes 1.1 and 1.2, sampling to obtain blood from positive donors reduces the maintenance of the blood supply. Frequently, no assessment of cross-reactivity takes place to determine the occurrence of blood incompatibility. We note that cross-reactivity does not impede the sensitization of receivers (CALLAN et al., 1995; TOCCI; EWING, 2009).

Flow cytometry is widely applied in hematology, not only to identify cell phenotypes but also to detect antibodies (NAKAGE et al., 2005; RAMOS-VARA et al., 2011). Ata et al. (2012) reported an anti-A2 antibody in humans that received incompatible renal transplant. This method has also been used in veterinary hematology to detect DEA 1 from antibodies using this methodology. Lucidi et al. (2011) researched DEA 1 in platelets but did not identify it while Polak et al. (2015) used the technique to research DEA 1 in erythrocytes using this methodology.

Since research into post-transfusion alloantibodies is limited, the present investigation was performed to identify the presence of antibodies anti-DEA 1 in dogs undergoing blood transfusions and compare results obtained from flow cytometry assay with those from crossmatching techniques. This study also investigated the progression of the production of antibodies against DEA 1 in dogs who received red blood cell products.

\section{Materials and Methods}

The project was approved by the Ethics Committee on Animal Use of the Institute of Health Sciences/Federal University of Bahia (Protocol No. 048/2013). The owners of the study animals were informed of the work methodology and signed the Instrument of Consent.
Eighteen applicant donor dogs whose laboratory blood count tests and biochemical analyses were within the normal range for the species were selected. The dogs also tested negative for the following diseases: ehrlichiosis, babesiosis, heartworm and leishmaniasis. Donor dog blood typing was performed using the chromatographic technique with the Alvedia ${ }^{\circ}$ (Limonest, France) commercial kit, in line with the manufacturer-recommended method.

The donor group consisted of eight males and ten female dogs of various breeds, including eight Afghan Hounds, one Doberman, one Fila Brasileiro, two Labradors and six Belgian Malinois Shepherds, with an average age of 4.8 years and an average weight of $34.7 \mathrm{~kg}$. Selected bags of fresh whole blood were processed no more than two days following collection to prevent hemolytic storage lesion, in line with Duggan (2011) and McDevitt et al. (2011).

The group of recipient animals was composed of 33 dogs recommended for blood transfusion, from a variety of breeds (five Rottweilers, four Yorkshire terriers, one Chow, one Doberman Pinscher, one Schnauzer, eight Poodles, one Maltese, one Golden Retriever, one Akita, two Pit Bulls, one Labrador Retriever and seven mongrels), 14 males and 19 females, with an average age of 7.4 years.

Whole blood from DEA 1-classified samples was used for transfusion to the receiver group following compatibility evaluation using crossmatching, as described by Lanevschi and Wardrop (2001). The crossmatching results were based on the degree of agglutinated erythrocytes, classified according to Gibson (2007) with intensity varying from zero to four crosses. Sheep polyclonal anti-dog $\operatorname{IgG}$ AA132F FITC AbD Serotec ${ }^{\oplus}$ (Bio-Rad, Hercules, CA, USA) was used for the flow cytometry, which was performed on a Becton Dickinson FACSCalibur ${ }^{\mathrm{rm}}$ interfaced with a Power Macintosh computer (Apple, Salvador, BA, Brazil, performed at the Immunology Laboratory of the Federal University of Bahia) with instrument-specific computer software (BD CellQuest Pro ${ }^{\text {tw }}$ software, Becton, Dickinson and Company). The steps were as follows:

- identification of anti-DEA 1 antibodies in the receivers via crossmatching assay on posttransfusion days 7, 14, 21 and 28;

- detection of anti-DEA 1 antibodies in the receivers through flow cytometry on post-transfusion days $7,14,21$ and 28 ;

- comparing the antibody screening results from the flow cytometry with those from the crossmatching performed on post-transfusion days $7,14,21$ and 28. 
The search for anti-DEA 1 antibodies followed the method used by Lucidi et al. (2011), with adjustments arising from the use of the erythrocyte antigen, since the original protocol used platelets. We maintained the test cell control for the detection of anti-DEA 1 antibodies using the same red blood cells from a DEA 1-positive dog blood donor. The negative control serum was obtained from an animal known to be DEA 1-negative, and the same sample was used throughout the study. The anti-DEA 1 antibodypositive serum obtained from the receiver animal's blood was added to the total polyclonal FITC-conjugated IgG. The cut-off point was based on a comparison of the negative results from the crossmatching tests with those from the flow cytometry.

The experimental procedure consisted of centrifuging $2 \mathrm{ml}$ of EDTA whole blood with 6 million DEA 1-positive erythrocytes per $\mathrm{dL}$ at $2200 \mathrm{x}$ g for 3 minutes. The plasma was discarded, and the packed red blood cells were resuspended in the same saline volume. Two $\mu \mathrm{L}$ of this concentrate was then mixed with $998 \mu \mathrm{L}$ of saline and homogenized by vortexing the solution. The test and negative control serum samples, each containing $50 \mu \mathrm{L}$, were incubated at $56^{\circ} \mathrm{C}$ for 10 minutes and then incubated with $40 \mu \mathrm{L}$ of the diluted erythrocyte solution at room temperature for 30 minutes. Serum samples with erythrocyte suspension were washed in saline three times by centrifugation at $2200 \mathrm{x}$ g for 3 minutes. Sera were added to the vials for testing and to the negative control, and the samples were incubated with $3 \mu \mathrm{L}$ of anti-dog IgG antibody at room temperature, protected from light, for 30 minutes. The samples were then washed in saline at $2200 \mathrm{x}$ g for 3 minutes. The sera in all vials were resuspended twice in $300 \mu \mathrm{L}$ of saline and, finally, cytometry readings were made.

Statistical analyses were used to assess the results of the crossmatching and cytometry analyses of DEA 1 antibodies.
The mean and standard deviations of the 33 individuals were surveyed over the four-week period. The comparison between flow cytometry was performed using ANOVA with the post-hoc Tukey test. Since crossmatching is an ordinal variable, the comparisons were analyzed using the Chi square test. The analyses were considered statistically significant at $\mathrm{p}<0.05$. All analyses were performed using the Statistical Package for Social Sciences (SPSS), version 17.0. The data were graphically displayed using Prism 5 software, version 5.01 .

\section{Results}

A total of 9 (27\%) out of the 33 tested dogs were positive for the presence of anti-DEA 1 antibodies using flow cytometry, while 15 animals (45\%) from the same group of dogs tested positive through crossmatching with DEA 1-positive blood samples.

Differences were observed in the animals in varied crossmatching intensity in the four weeks following transfusion (Table 1). Table 2 shows the number of blood receivers, with the number of crosses representing crossmatching intensity over the four study weeks.

The flow cytometry analysis for individuals who evidenced crossmatching resulted in negative values ranging from 4 to 14.6 in fluorescence intensity. Samples that obtained values above 14.6 were considered positive; these values ranged from 15 to 538.99. The average number of anti-DEA 1 antibodies obtained in the first week was $6.714 \pm 2.436$, rising to $9.431 \pm 1.129$ in the second week. In the third week, the average increased to $16.200 \pm 23.70$, while the highest value in the fourth week was $38.570 \pm$ 96.98 (Table 3). However, significant differences were only observed between the first and fourth $(p=0.026)$, and the second and fourth weeks $(\mathrm{p}=0.038)$.

Figures 1 and 2 show the results of the crossmatching and flow cytometry assays by columns, as seen below.

Table 1 - Crossmatching (score) results for 33 post-ransfusion dogs with DEA 1-positive blood

\begin{tabular}{ccccc}
\hline Positive & $\mathbf{7}$ days & $\mathbf{1 4}$ days & $\mathbf{2 1}$ days & $\mathbf{2 8}$ days \\
\hline & $0.121 \pm 0.4846$ & $0.576 \pm 1.1465$ & $0.939 \pm 1.4129$ & $1.333 \pm 1.6708$ \\
\hline
\end{tabular}

$(\mathrm{n})=33$ animals. Mean and Standard deviation (Pearson; $\mathrm{p}=0.001$ )

Table 2 - Intensity of crosses from the crossmatching test of 33 post-transfusion dogs with DEA 1 positive blood evaluated over four weeks

\begin{tabular}{ccccc}
\hline Crosses & 7 days & 14 days & 21 days & 28 days \\
\hline 0 & 31 & 26 & 22 & 19 \\
2 & 2 & 2 & 4 & 4 \\
3 & 0 & 5 & 5 & 4 \\
4 & 0 & 0 & 2 & 6 \\
\hline
\end{tabular}

(n) $=33$ animals 
Table 3 - Evaluation of number of anti DEA 1-antibodies in dogs from flow cytometry in the four weeks following DEA 1-positive blood transfusion

\begin{tabular}{ccccc}
\hline & First week & Second week & Third week & Fourth week \\
\hline Flow cytometry & $6.714 \pm 2.436$ & $9.431 \pm 11.29$ & $16.200 \pm 23.70$ & $38.570 \pm 96.98$ \\
\hline
\end{tabular}

$(\mathrm{n})=33$ animals. Mean and Standard deviation (ANOVA; $\mathrm{p}=0.017)$

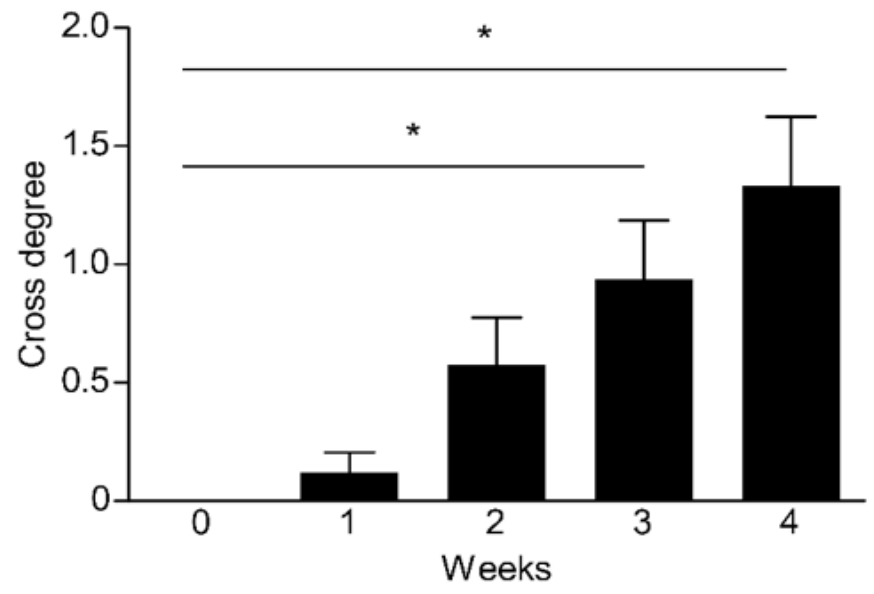

Figure 1 - Evidence of the gradation of cross-reactions from the crossmatching compatibility test for the blood transfusion receiver dogs (week 0 ) and $7,14,21$ and 28 days post transfusion (weeks $1,2,3$ and 4 ). $(\mathrm{p}=0,001)$
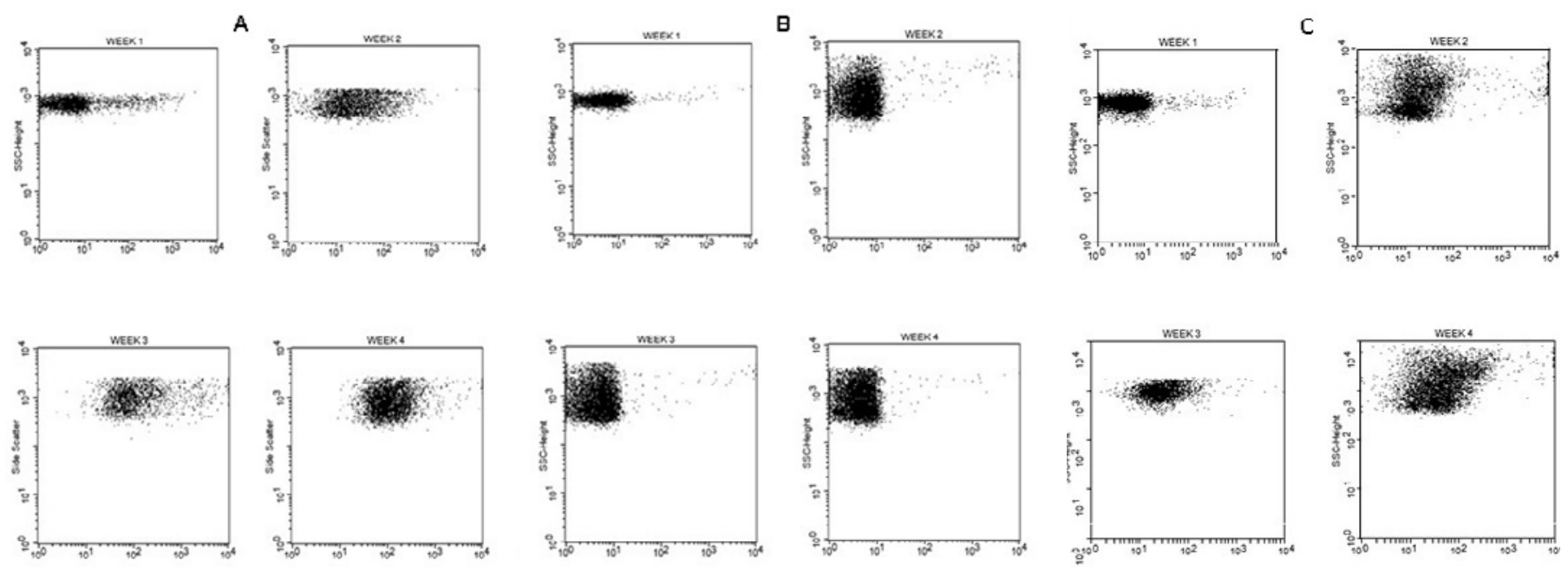

Figure 3 - Flow cytometric analysis of the dog population analyzed. Positive control means presence of antibodies anti-DEA 1. Scatterplots of fluorescence intensity showed increased reaction antigen-antibody in the four weeks studied (A). The fluorescence intensity showed a clear difference between the positive reaction and the negative reaction. Negative control (B). A typical positive test that revealed antibodies anti-DEA 1 in the four weeks studied (C). All tests used forward scatter of 10000 gated events

Figure 3 has evidenced a clear distinction between positive and negative flow cytometric results. Positive control results for erythrocyte autofluorescence with the presence of the antibodies anti-DEA 1 and the negative control results for erythrocyte autofluorescence were low.

\section{Discussion}

The blood donor group represented type DEA 1-positive individuals. In the literature, the DEA 1 results for the typing parameters of the canine population in Brazil are extremely high (NOVAIS et al., 1999; ESTEVES et al., 2011; SOUZA et al., 2014). Acierno et al. (2014), observed the prevalence of DEA 1 among the world's dog population varies between 10 and $100 \%$ and is more prevalent within racial groups or due to close inbreeding, compared to genetically mixed populations, resulting in a worldwide estimate of $50 \%$. In our group of donor animals, we observed that all the dogs from the Belgian Malinois Shepherd and 
Afghan Hound breeds were type DEA 1. This finding demonstrated that the racial factor was an autosomal dominant trait, as reported by lazbik et al. (2010).

Autoagglutination was observed in some patients during the crossmatching tests. According to Callan et al. (1995), incompatibility reactions in a patient with DEA 1-negative erythrocytes suggest the existence of naturally occurring alloantibodies against the DEA 3, DEA 5 and DEA 7 types, as well as the DEA 1, representing a high frequency of antigenicity. In the flow cytometry study, the test sera were incubated at $56{ }^{\circ} \mathrm{C}$ to deactivate the complement system, which, given the observed interference from agglutination (LUCIDI et al., 2011), optimized the technique. In this study, we observed that the positivity in the crossmatching test was markedly progressive from the second to the fourth week, while there was a reduction in the cross parameter in some individuals during the fourth week. In subjects with a positive flow cytometry test, growth was evidenced numerically following the first week and positive progression continued until the fourth week, thereby confirming the technique's high specificity. Some individuals were crossmatching-positive but flow cytometry-negative, which suggested that they were individuals with alloantibodies for DEA 3, 5 and 7 or with autoantibodies and the auto agglutination typical of autoimmune hemolytic anemia, as mentioned by Blois et al. (2013).

As noted, only nine (27\%) of the animals evaluated over the four weeks demonstrated positivity to the DEA 1 antigen in the flow cytometry, whereas fifteen (45\%) animals were positive in the crossmatching tests. Of these fifteen positive animals, seven were negative in the flow cytometry test. These results suggest that other erythrocyte antibodies were possibly involved, since other DEA types might have been present but were not identified in the study. Of the nine animals that were positive in the flow cytometry, only one was negative in crossmatching. This animal only demonstrated mild positivity (numerical fluorescence 20 for a cut-off of 14.7) in the third week of the study. This result demonstrates that crossmatching has a semi-quantitative nature and agglutination may not therefore be noticeable for a low antibody titer. All the animals who presented with higher fluorescence demonstrated positivity in the crossmatching test.

These findings highlight a relationship between the two techniques, thus: flow cytometry proved to be a high specificity technique, whereas the crossmatching test demonstrated high sensitivity. However, the crossmatching test may provide false positives, thus rendering inaccurate any comparison between the two approaches. As described in the literature, there is no gold standard technique for blood typing. Flow cytometry was used by Acierno et al. (2014) and Polak et al. (2015) because of its high specificity and the possibility of detecting alloantibodies. The data confirm that flow cytometry is indeed highly specific for the detection of alloantibodies. However, in practice, this technique is of limited access, due to its high cost, while crossmatching remains highly accessible in clinical practice, due to its low cost. Despite its specificity limitations, crossmatching remains a viable choice for pre-transfusion testing.

Blood transfusion is a complex and varied cell therapy, and the most common exposure route for a high concentration of antigens (ZIMRING, 2013). Its effects generate direct alloimmunization, which is the target of the antibodies in this study. It is not yet clear whether weak DEA 1-positive dogs can trigger an alloantibody response like the response detected in strong DEA 1-positive dogs (ACIERNO et al., 2014). To standardize the technique, we obtained samples of cells with the antigen at different DEA 1 intensities. Our flow cytometry survey used polyclonal (Serotec) sheep anti-dog antibodies, which were inherently variable and had multiple targets. Moreover, their agglutination reactions appeared to depend on antiserum concentration (ACIERNO et al., 2014; POLAK et al., 2015). The intensity of each serum sample we tested was dependent on donor DEA 1, which ranged from slightly to strongly positive. Each sample therefore had a distinct positive value, despite varying degrees of intensity.

\section{Conclusions}

The detection of antibodies and the evidence of crossmatching demonstrate that the flow cytometry technique has high specificity and sensitivity.

Animals that did not show positivity in the crossmatching and flow cytometry tests following blood transfusion were considered different from all other DEA 1-positive blood groups.

\section{Acknowledgements}

This work was supported by the Diagnose Animal Veterinary Clinic in Bahia, the Immunology Laboratory of the Federal University of Bahia, and the Neurochemical Laboratory of the Federal University of Bahia, in Brazil. 


\section{References}

ACIERNO, M. M.; RAJ, K.; GIGER, U. DEA 1 expression on dog erythrocytes analysed by immunochromatographic and flow cytometric techniques. Journal of Veterinary Internal Medicine, v. 28, n. 2, p. 592-598, 2014. doi: 10.1111/jvim.12321.

ATA, P.; CETINKAYA, F.; OZGEZER, T.; OZEL, L.; TUlUNAY, A.; EKSIOGLU, E.; TITIZ, M. I. Flow cytometric detection of anti-AB antibody titers in blood group $\mathrm{O}$ recipients of blood group A2 donor kidneys. Transplantation Proceedings, v. 44, n. 6, p. 1706-1709, 2012. doi: 10.1016/j.transproceed.2012.05.051.

BLAIS, M. C.; BERMAN, L.; OAKLEY, D. A.; GIGER, U. Canine Dal blood type: a red cell antigen lacking in some Dalmatians. Journal of Veterinary Internal Medicine, v. 21, n. 2, p. 281-286, 2007. doi: 10.1111/j.1939-1676.2007.tb02961.x.

BLOIS, S. L.; RICHARDSON, D. M.; ABRAMS-OGG, A. C. Comparison of a gel column blood typing method and a point-of-care cartridge for dog erythrocyte antigen 1.1. Journal of Veterinary Emergency and Critical Care, v. 23, n. 3, p. 340-343, 2013. doi: $10.1111 /$ vec. 12052 .

CALLAN, M. B.; JONES, L. T.; GIGER, U. Hemolytic transfusion reactions in a dog with an alloantibody to a common antigen. Journal of Veterinary Internal Medicine, v. 9, n. 4, p. 277-279, 1995. doi: 10.1111/j.1939-1676.1995.tb01080.x.

DAVIDOW, B. Transfusion medicine in small animals. Veterinary Clinics of North America Small Animal Practice, v. 43, n. 4, p. 735-756, 2013. doi: 10.1016/j.cvsm.2013.03.007.

DUGGAN, J. M. Blood transfusion: old blood, new blood or no blood. Internal Medicine Journal, v. 41, n. 4, p. 358-359, 2011. doi: 10.1111/j.1445-5994.2011.02455.x.

ESTEVES, V. S.; LACERDA, L. A.; LASTA, C. S.; PEDRALLI, V.; GONZÁLEZ, F. H. D. Frequencies of DEA blood types in a purebreed canine blood donor population in Porto Alegre, RS, Brazil. Pesquisa
Veterinária Brasileira, v. 31, n. 2, p. 178-181, 2011. doi: 10.1590/S0100-736X2011000200015.

GIBSON, G. Transfusion medicine. In: KING, L. G.; BOAG, A. Bsava Manual of Canine and Feline Emergency and Critical Care. 2. ed. Quedgeley: British Small Animal Veterinary Association, 2007. p. 215-227.

GIGER, U. Blood typing and crossmatching to ensure blood compatibility. In: BONAGURA, J. D., TWEDT, D. C. (Eds.). Kirk's current veterinary therapy $\mathbf{X V}$. Philadelphia: Saunders, 2014. p. 143-147.

IAZBIK, M. C.; O’DONNELL, M.; MARIN, L.; ZALDIVAR, S.; HUDSON, D.; COUTO, C. G. Prevalence of dog erythrocyte antigens in retired racing Greyhounds. Veterinary Clinical Pathology, v. 39, n. 4, p. 433-435, 2010. doi: 10.1111/j.1939-165X.2010.00261.x.

KESSLER, R. J.; REESE, J.; CHANG, D.; SETH, M. HALE, A. S.; GIGER, U. Dog erythrocyte antigens $1.1,1.2,3,4,7$, and Dal blood typing and crossmatching by gel column technique. Veterinary Clinical Pathology, v. 39, n. 3, p. 306-316, 2010. doi: 10.1111/j.1939-165X.2010.00249.x.

KOHN, B.; CLASSE, G.; WEINGART, C. Clinical evaluation of the Quick Vet/RapidVet canine dog erythrocyte antigen 1.1 blood-typing test. Journal of Veterinary Diagnostic Investigation, v. 24, n. 3, p. 539-545, 2014. doi: $10.1177 / 1040638712442880$.

LANEVSCHI, A.; WARDROP, K. J. Principles of transfusion medicine in small animals. Canadian Veterinary Journal, v. 42, n. 6, p. 447-454, 2001.

LUCIDI, C. A.; TAKAHIRA, R. K.; GERLACH, J. A.; DAVIS, J. M.; SCHWARTZ, K. A.; SCOTT, M. A. Flow cytometric assessment of canine erythrocytes and platelets for dog erythrocyte antigen 1.1. Veterinary Clinical Pathology, v. 40, n. 4, p. 435-443, 2011. doi: 10.1111/j.1939-165X.2011.00374.x.1.

MCDEVITT, R. I.; RUAUX, C. G.; BALTZER, W. I. Influence of transfusion technique on survival of 
autologous red blood cells in the dog. Journal of Veterinary Emergency and Critical Care, v. 21, n. 3, p. 209-216, 2011. doi: 10.1111/j.1476-4431.2011.00634.x/abstract.

NAKAGE, A. P. M.; SANTANA, A. E.; CAPUA, M. L. B.; COELHO, P. S. Metodologia e aplicação da citometria de fluxo na hematologia veterinária. Ciência Rural, v. 35, n. 4, p. 966-973, 2005. doi: 10.1590/S0103-84782005000400040.

NOVAIS, A. A.; SANTANA, A. E.; VINCENTIN, L. A. Prevalência do grupo sanguíneo DEA 1 (subgrupos 1.1 e 1.2) em cães (Canis familiaris, Linaeus, 1758) criados no Brasil. Brazilian Veterinary Journal Animal Science, v. 36, n. 1, p. 23-27, 1999. doi: 10.1590/S1413-95961999000100004.

POLAK, K.; ACIERNO, M. M.; RAJ, K.; MIZUKAMI, K.; SIEGEL, D. L.; GIGER, U. Dog erythrocyte antigen 1: mode of inheritance and initial characterization. Veterinary Clinical Pathology, v. 44, n. 3, p. 369-379, 2015. doi: 10.1111/vcp.12284.

RAMOS-VARA, J. A.; AVERY, A. C.; AVERY, P. R. Técnicas avançadas de diagnóstico. In: RASKIN, R. E.; MEYER,
D. J. Citologia clínica de cães e gatos: atlas colorido e guia de interpretação. 2. ed. Rio de Janeiro: Elsevier, p. 395-437, 2011.

SOUZA, S. L.; STOPIGLIA, A. J.; GOMES, S. G. R.; ULATA, S. K.; MOROZ, L. R.; FANTONI, D. T. Estudo da frequência dos antígenos eritrocitários caninos 1, 1.1 e 7 e risco de transfusão incompatível em cães de diferentes raças e mestiços da região metropolitana da cidade de São Paulo-SP, Brasil. Brazilian Journal of Veterinary Research and Animal Science, v. 51, n. 4, p. 316-323, 2014. doi: 10.11606/issn.1678-4456.v51i4p316-323.

TOCCI, L. J.; EWING, P. J. Increasing patient safety in veterinary transfusion medicine: an overview of pretransfusion testing. Journal of Veterinary Emergency and Critical Care, v. 19, n. 1., p. 66-73, 2009. doi: 10.1111/j.1476-4431.2009.00387.x.

ZIMRING, J. C. Regulation of immune responses by RBC transfusion. International Society of Blood Transfusion, n. 8, p. 181-184, 2013. doi: 10.1111/voxs.12042. 